\title{
Developmental-induced changes of metabolic and antioxidant responses in the skeletal muscles of sea trout (Salmo trutta L.)
}

\author{
Natalia Kurhaluk, Halyna Tkachenko
}

Received - 26 November 2019/Accepted - 26 May 2020. Published online: 30 June 2020; ๑Inland Fisheries Institute in Olsztyn, Poland Citation: Kurhaluk N., Tkachenko H. 2020 - Developmental-induced changes of metabolic and antioxidant responses in the skeletal muscles of sea trout (Salmo trutta L.) - Fish. Aquat. Life 28: 77-90

\begin{abstract}
The goal of the current study was to characterize developmental-induced changes of the metabolic and antioxidant responses in the skeletal muscles of the anadromous sea trout (Salmo trutta L.) from the Baltic Sea and its catchment area rivers. Activities of the metabolic enzymes, i.e., lactate dehydrogenase, succinate dehydrogenase, alanine and aspartate aminotransferases, their ratios representing aerobic, anaerobic, and amino acid metabolisms, the level of the metabolites (pyruvate and lactate), the activities of several key antioxidant enzymes (superoxide dismutase, catalase, glutathione peroxidase, and reductase), and a marker of lipid peroxidation (2-Thiobarbituric acid reactive substances, TBARS) were evaluated. The current study revealed the impact of the sex and different developmental stages of the sea trout (parr, smolts, spawners, adults, and kelts) on the effective formation of adaptive oxygen-dependent mechanisms. A stable developmental-related tendency toward increased lipid peroxidation in muscle tissues was observed. Glutathione peroxidase in muscle tissues played a leading role in the different stages of trout development. A switch of the muscle cytosolic redox potential from the aerobic pathway to anaerobic glycolysis was observed. These results indicated that energy-related cellular components and metabolic enzymes could compensate for adaptive mechanisms without any serious damage to muscle tissues. The differences in the enzyme activities were associated with the reorganization of
\end{abstract}

N. Kurhaluk [ $\left.\Xi^{\circ}\right]$, H. Tkachenko

Department of Zoology and Animal Physiology, Institute of Biology

and Earth Sciences, Pomeranian University in Słupsk

Arciszewski Str. 22b, 76-200 Słupsk, Poland

e-mail: nataliakurhaluk@gmail.com the energy-related metabolic pathways (anaerobic and aerobic pathways) during spawning. This process was one of the adaptation mechanisms of this fish.

Keywords: metabolic alteration, antioxidant defense, developmental changes, sea trout, Baltic Sea

\section{Introduction}

The sea trout is of especially high economic and social importance as a resource in aquaculture, water management, recreational angling in both fresh water and seawater, and is a main source of protein in the human diet (Pedersen et al. 2006, Dziewulska et al. 2008, Dal Bosco et al. 2013, Kurhaluk 2019). Since the sea trout is an anadromous fish, impacts of freshwater and seawater factors coexist (Debowski et al. 1999). Information on the behavior, habitat use, and life-history strategies depend on fish sex (Martínez et al. 2014, Maitre et al. 2017, Costantini 2018).

One of the characteristics of some salmonids is that they change habitats from fresh to saline waters and vice versa during spawning. This requires alterations in the physiological and biochemical states of the fish and their adaptive potential. Therefore, using biochemical indicators is appropriate to evaluate 
developmental- and habitat-influenced fish metabolism. These include the AlAT and aspartate aminotransferase (AsAT) enzymes, since their molecular systems react quickly to changes in energy metabolism (aerobic and anaerobic pathways) as shown by Gabriel et al. (2012). Changes in their activity are fundamentally important not only for energy pathways but also for the early diagnosis of biosynthetic and detoxifying functions in the fish. The ratio of the serum AsAT and AlAT activities is known as the De Ritis ratio (AsAT/AlAT) (Botros and Sikaris 2013).

Fish possess effective mechanisms to counteract the harmful effects of oxidative stress, i.e., enzymatic [superoxide dismutase (SOD), catalase (CAT), glutathione reductase (GR) and glutathione peroxidase (GPx)] and non-enzymatic lower molecular weight substances [glutathione, vitamins C, E, and $\mathrm{K}$, and carotenoids] (Halliwell and Gutteridge 2007, Guéraud et al. 2010). By developing antioxidant defenses, fish protect their cells against the oxidation of proteins, DNA, steroid components, and the peroxidation of unsaturated lipids in cell membranes (Martines-Alvares et al. 2005).

Sea trout are anadromous, while brown trout are the resident forms of the same species - Salmo trutta L. The parr developmental stage occurs at the age of 2-3 years when the fish inhabit fresh water. This form persists until the fish migrate to the sea. Some juvenile sea trout do not smoltify during their first seaward migration and are indistinguishable from brown trout parr (Pemberton 1976, Ferguson et al., 2019). In the smolt stage, trout species reach sizes of $10-20 \mathrm{~cm}$; this is a two-habitat stage, because it is when the fish migrate to the sea. The adult developmental stage includes individuals that return to the rivers as adult specimens after inhabiting the sea for two to three years. The fish reach weights of $2-3 \mathrm{~kg}$, are sexually mature, and are characterized by the silver color of the lateral parts of their bodies (Birt and Green 1986, Debowski et al. 1999). During migration, adults do not feed. Fish that have spawned but have not yet recovered or commenced new growth are know as kelts (Pratten and Sherarer 1983).
Studies of the possibilities of the basic mechanisms in trout for adapting during freshwater and marine migrations are still important. In contrast to research on the Atlantic salmon, Salmo salar L. (Amundsen and Gabler 2008), the basic mechanisms of oxidative stress, aerobic and anaerobic metabolic status caused by changes in the environments inhabited from fresh water to seawater and vice versa in sea trout populations have yet to be explained. Thus, the aim of our study was to evaluate developmental-induced changes in oxidative stress biomarkers, i.e., lipid peroxidation and antioxidant defenses (superoxide dismutase, catalase, glutathione reductase, and glutathione peroxidase) and energy-related metabolites, i.e., lactate and pyruvate levels, and the activities of lactate dehydrogenase, succinate dehydrogenase, and aminotransferases in skeletal muscle growth in sea trout, Salmo trutta L. These findings revealed the effects of sex (males, females) and developmental stage (parr, smolts, adults, spawners) on muscular oxygen-dependent processes and on aerobic and anaerobic pathways and metabolic substrate levels.

\section{Materials and methods}

\section{Characteristics of the study area}

The Słupia River in the central Pomerania region is one of the best-known rivers among anglers. The Słupia is a coastal river, and the whole of its basin lies within the Pomeranian Voivodship (northern Poland). The Słupia is classified as a mountain river as its source is located near Sierakowska Huta, 178 m above sea level. The middle course of the Słupia River is located in the Polanowska Upland and the lower course is in the Damnica Upland, the Słupsk Plain, and the Słowiński Coast. The river flows in to the Baltic Sea at the town of Ustka. The Słupia River tributaries from from which migratory trout specimens were collected are shown in Fig. 1. Analysis indicated that the water quality in the Słupia in the vicinity of the city of Słupsk was of the first class of 


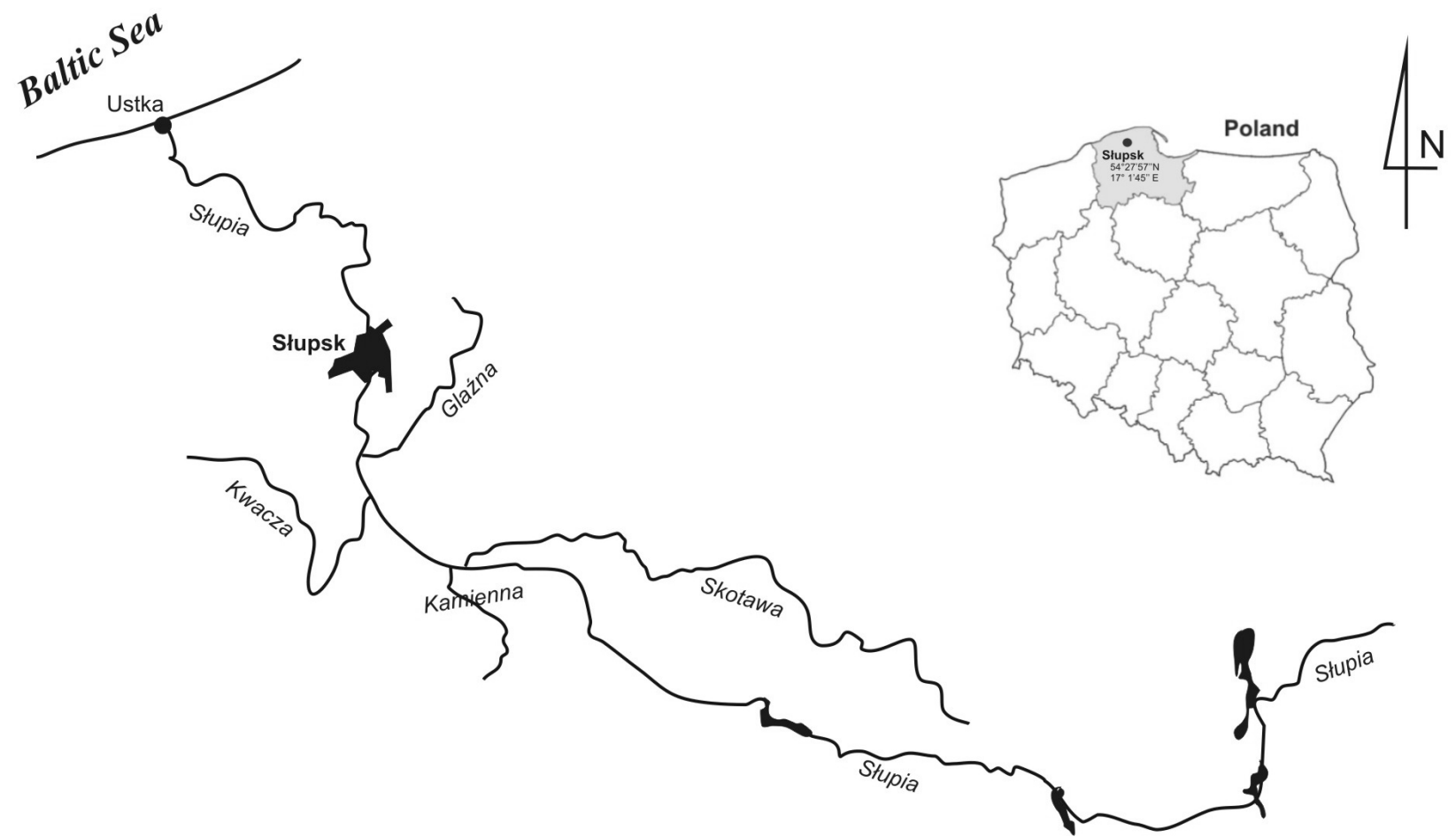

Figure 1. Map of the Pomeranian region in northern Poland with the location of Słupsk marked where sea trout $(S$. trutta) samples were collected.

purity according to European standard EN ISO 8689-2 and the Water Framework Directive as (Obolewski 2010).

\section{Characteristics of fish groups}

The study material was sampled from 2008 to 2014 and included 397 specimens of sea trout in various developmental stages: parr $(n=113)$, smolts $(n=$ 122 ), adults ( $\mathrm{n}=25$, i.e., 13 males, 12 females), spawners ( $\mathrm{n}=113$, i.e., 60 males, 53 females), and kelts ( $n=24$, i.e., 12 males, 12 females). The trout specimens in the parr and smolt developmental stages were caught in the Pomeranian rivers of Glazna, Skotawa, Kamienna, and Kwacza near Słupsk (Fig. 1). Sexual dimorphism is well-expressed in adults, spawners, and kelts; the analysis was carried out according to sex since the phenotypic males and females possessed testicular and ovarian structures. We analyzed various stages of fish development, and changes in the neurohormonal levels determining sex were expressed (testicular and ovarian structures, eggs). We also investigated fish morphological parameters (mean body mass, mean body length) and aging according to Jensen and Johnson (1982).

Adult sea trout specimens were caught in the es-

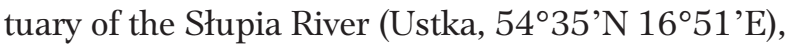
and sexually mature spawners and kelts (males and females) were caught in the Słupia River (Słupsk, Pomeranian Voivodeship, northern Poland; $\left.54^{\circ} 27^{\prime} 57^{\prime}{ }^{\prime} \mathrm{N} 17^{\circ} 1^{\prime} 45^{\prime \prime} \mathrm{E}\right)$. The fish were caught with the electric fishing method using a power generator with a DC adapter in close cooperation with the Dolina Słupia Landscape Park and the District Board of the Polish Angling Association in Słupsk (environmental license DROS.AR.MW.6052-16/10).

The fish were euthanized with percussion stunning followed by brain destruction. Tissues were sampled for analysis. Tissue samples were collected, frozen $\left(-80^{\circ} \mathrm{C}\right)$, and homogenized in the laboratory of the Department of Zoology and Animal Physiology, Institute of Biology and Earth Sciences, Pomeranian University in Słupsk. 


\section{Tissue isolation}

The sea trout muscle tissue samples were homogenized in ice-cold buffer (100 mM Tris-HCl, $\mathrm{pH}$ 7.2). Minced muscle tissues were rinsed clear of blood with the cold isolation buffer and homogenized in a H500 homogenizer with a motor-driven pestle on ice. Homogenates were centrifuged at 3,000 g for 15 min at $4{ }^{\circ} \mathrm{C}$. After centrifugation, the supernatant was collected and frozen at $-20^{\circ} \mathrm{C}$ until analyzed. Protein contents were determined with the method described by Bradford (1976) with bovine serum albumin as the standard. Absorbance was recorded at $595 \mathrm{~nm}$. All enzymatic assays were carried out at $22 \pm 0.5^{\circ} \mathrm{C}$ using a Specol 11 spectrophotometer (Carl Zeiss Jena, Germany) in duplicate. The enzymatic reactions were started by adding the tissue supernatant.

\section{Biochemical assays}

\section{2-Thiobarbituric acid reactive substances (TBARS) assay}

Lipid peroxidation was evaluated by the production of 2-thiobarbituric acid-reactive substances (TBARS). An aliquot of the homogenate was used to determine the lipid peroxidation status of the sample by measuring the concentration of 2-thiobarbituric-acid-reacting substances (TBARS), according to the method of Kamyshnikov (2004). TBARS values were reported as nmoles of malonic dialdehyde (MDA) per mg protein.

\section{Superoxide dismutase activity assay}

Superoxide dismutase (SOD, E.C. 1.15.1.1) activity was assessed by its ability to dismutate superoxide produced during quercetin auto-oxidation in an alkaline medium (pH 10.0) by the Kostiuk et al. (1990) method. Activity is expressed in units of SOD per mg of tissue protein.

\section{Catalase activity assay}

Catalase (CAT, E.C. 1.11.1.6) activity was determined by measuring the decrease of $\mathrm{H}_{2} \mathrm{O}_{2}$ in the reaction mixture using a spectrophotometer at a wavelength of $410 \mathrm{~nm}$ by the method of Koroliuk et al. (1988). One unit of catalase activity is defined as the amount of enzyme required for the decomposition of $1 \mu \mathrm{mol} \mathrm{H} \mathrm{H}_{2} \mathrm{O}_{2}$ per min per mg of tissue protein.

\section{Glutathione reductase activity assay}

Glutathione reductase (GR, EC 1.8.1.7) activity was determined according to the colorimetric method by Glatzle et al. (1974) based on $\mathrm{NADPH}_{2}$ oxidation in the presence of GSSG. The specific GR activity is expressed as nmol NADPH per min per mg of tissue protein.

\section{Glutathione peroxidase activity assay}

Glutathione peroxidase (GPx, EC 1.11.1.9) activity was determined by detecting the non-enzymatic utilization of GSH (the reacting substrate) at an absorbance of $412 \mathrm{~nm}$ after incubation with 5,5-dithiobis-2-nitrobenzoic acid (DTNB) according to by the method of Moin (1986). The rate of GSH reduction was followed spectrophotometrically at 412 $\mathrm{nm}$. GPx activity is expressed as $\mu \mathrm{mol}$ GSH per min per mg of tissue protein.

\section{Alanine aminotransferase and aspartate aminotransferase activities assay}

Alanine aminotransferase (AlAT, EC 2.6.1.2) and aspartate aminotransferase (AsAT, EC 2.6.1.1) activities were analyzed spectrophotometrically with a standard enzymatic method described by Reitman and Frankel (Reitman and Frankel 1957). Pyruvate was used as the standard for calibrating the curve in the calculation of both AsAT and AlAT activities. One unit of AsAT or AsAT is defined as the liberation of $1 \mu \mathrm{mol}$ of pyruvate per hour at $37^{\circ} \mathrm{C}$ incubation per $1 \mathrm{mg}$ of tissue protein. 


\section{Lactate dehydrogenase activity assay}

Lactate dehydrogenase (LDH, EC 1.1.1.27) activity was determined with the colorimetric method by Sevela and Tovarek (1959). The principle of the method is based on pyruvate to lactate reduction catalyzed by $\mathrm{LDH}$ in the presence of $\mathrm{NAD}^{+}$. In the calculation of LDH activity, pyruvate is used as the standard for the construction of the calibration curve. One unit of $\mathrm{LDH}$ is defined as the formation of $1 \mu \mathrm{mol}$ of pyruvate per hour at $37^{\circ} \mathrm{C}$ incubation per $1 \mathrm{mg}$ of tissue protein.

\section{Succinate dehydrogenase activity}

Succinate dehydrogenase (SDH, EC 1.3.5.1) activity was analyzed spectrophotometrically with the method of Eschenko and Volski (1982). One unit of $\mathrm{SDH}$ activity is defined as the amount of enzyme required for decomposition of $1 \mathrm{nmol}$ succinic acid per min per mg of tissue protein.

\section{Lactate and pyruvate levels}

The level of lactate was determined by reaction with hydroquinone, while pyruvate was assessed with dimethylaminobenzaldehyde (Herasimov and Plaksina 2000). The absorbance was measured at $420 \mathrm{~nm}$ and $430 \mathrm{~nm}$, respectively. The calibration curve for lactate (0.1-5 mM) and pyruvate level (0.1-5 mM) was used, and results were expressed in nmol per mg of tissue protein.

\section{Statistical analysis}

The results were expressed as mean \pm S.D. All variables were tested for normal distribution using the Kolmogorov-Smirnov test ( $>0.05)$. The homogeneity of variance was assessed using Levene's test. The significance of differences in parameter values, and among all studied groups was determined using one-way analysis of variance (ANOVA) and multifactorial analysis of variance (MANOVA). Tukey's post-test was used for unequal observations (Zar 1999).
Statistical analysis was two-fold; biomarkers of oxidative stress were compared with those in each developmental stage of the sea trout, while metabolism biomarkers were analyzed separately. The combined effect of sex and developmental stages and its significance (the main effects) was compared with oxidative stress and biochemical parameter data separately. Differences were considered significant at $\mathrm{p}<0.05$.

To verify the hypothesis of the impact of sex and developmental stages on the antioxidant defense in muscle tissues, we evaluated these assumptions using multivariate analysis of variance (MANOVA) for two fish stages (adults, spawners) and kelts. These stages were selected because phenotypic males and females had well developed testicular and ovarian structures. Using multivariate significance tests (Wilks, Pillai, Hotelling, and Roy) of the main effects (sex, developmental stage, and their combined effects) permitted obtaining statistically significant relationships for all three values. In the model approach, to combine the impact of two factors (sex and developmental stage), we adopted a two-way classification model as follows:

$$
X_{i j k}=\mu+\alpha_{i}+\beta_{j}+(\alpha \beta)_{i j}+\varepsilon_{i j k},
$$

where $X_{\mathrm{ijk}}$ - the value of the dependent variable, $\mu$ - mean, $\alpha_{i}-$ main effect of the sex factor, $\beta_{j}-$ main effect of the developmental stage factor; $(\alpha \beta)_{i j}$ - the effect of the interaction of the sex and developmental stage factors; $\varepsilon_{\mathrm{ijk}}$ - random experimental error.

Associations among all data for all individuals were evaluated using Pearson's correlation analysis. The correlation and regression analysis comprised the correlation coefficient ( $\mathrm{r}$ ), the regression equation, and the significance of these dependencies (P). We used the coefficients of multiple correlation analysis $(R)$, the coefficient of determination $\left(R^{2}\right)$, and its corrected form reduced by random errors $\left(\mathrm{R}^{2}\right.$ adjusted) in data analysis for the description of the full model. We used the SS test to describe the share of all analyzed biomarkers of oxidative stress and biochemical parameters to assess the antioxidant barrier with the $\mathrm{F}$ test and its significance. All statistical calculations were performed on separate data from 
each individual with Statistica 8.0 software (StatSoft Inc., Poland).

\section{Results}

The analysis of the lipid peroxidation biomarker in the muscle tissues of sea trout at different developmental stages showed that the TBARS level was altered significantly $\left(\mathrm{F}_{7.364}=94.39, \mathrm{P}=0.000\right)$. Relevant data are shown in Fig. 2. Higher TBARS levels were observed in smolts compared with parr. Two-fold higher TBARS levels were noted in spawners and kelts in comparison with the first three stages of trout development. It should be noted that a stable tendency toward an age-related increase of lipid peroxidation in muscle tissues was observed. These changes were significant for spawners and kelts and did not differ between the sexes.

In the current study, the enzyme activities associated with the first and second antioxidant defense lines, namely SOD and CAT, exhibited the changes presented in Fig. 3. The highest SOD activity was observed in smolts, adult males and females, and kelt males and females. CAT activity $\left(\mathrm{F}_{7.364}=5.05\right.$, $\mathrm{P}=0.000$ ) exhibited a similar trend to SOD, i.e., a tendency to decrease in the adult stage with subsequent restoration of enzyme activity with age and developmental stage. We also observed enzyme activities in muscle tissues associated with glutathione metabolism, i.e., $\mathrm{GR}\left(\mathrm{F}_{7.364}=20.94\right.$, $\mathrm{P}$ $=0.000)$ and $\mathrm{GPx}\left(\mathrm{F}_{7.364}=141.54, \mathrm{P}=0.000\right)$. Statistically significant changes are presented in Fig. 4.

The highest GR activity was observed in parr and smolt developmental stages with a subsequent distinct tendency to decrease significantly statistically in smolts, male and female, spawners, and kelts. GPx activity exhibited the opposite trend to that of GR (Fig. 4b), and the tendency of GPx activity to increase was related to age and developmental stage. The reduced GPx activity noted in parrs, smolts, and adults increased significantly statistically in male and female spawners and kelts.

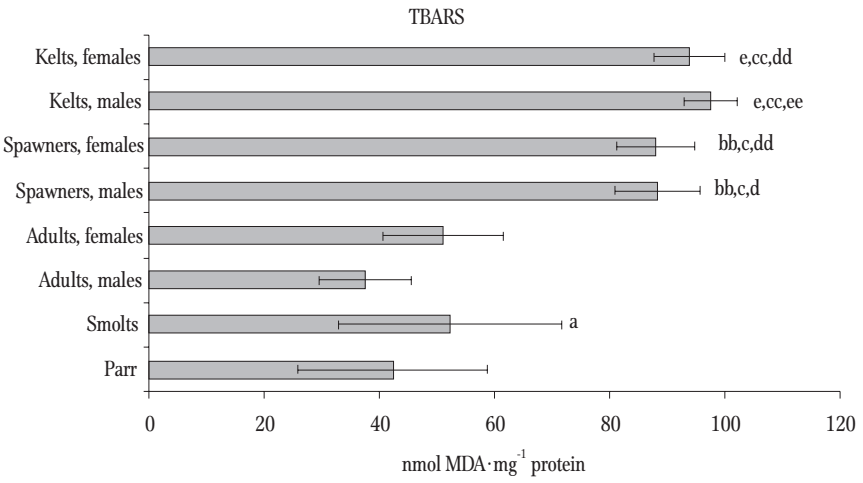

Figure 2. TBARS level (nmol MDA mg ${ }^{-1}$ protein) in muscle tissues of sea trout (S. trutta) at different developmental stages. Results are expressed as mean \pm S.D. Differences among groups were analysed with one-way ANOVA and Tukey's post-hock test for unequal observations. Differences are significant at $\mathrm{P}<0.05$.

Significant differences among groups were designated as follows: a smolt vs. parr; aa - adult males or females vs. parr; $b$ - adult males or females vs. smolt; bb - male or female spawners vs. parr; c - male or female spawners vs. smolts; cc - male or female kelts vs. smolts; $d$ - male spawners vs. adult males; dd - female spawners vs. adult females; e male or female kelts vs. parr; ee - male kelts vs. adult males; $f$ - female kelts vs. adult females; $\mathrm{ff}$ - male kelts vs. male spawners; $\mathrm{j}$ - female kelts vs. female spawners.

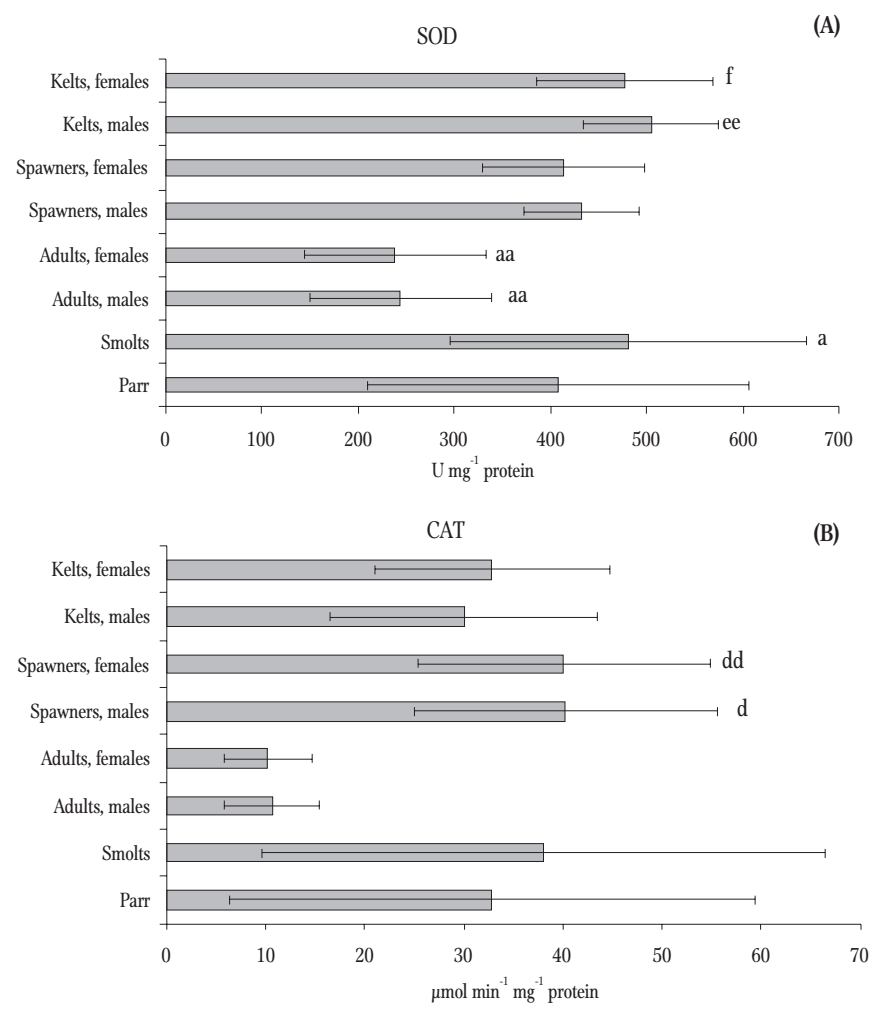

Figure 3. Superoxide dismutase activity ( $\mathrm{Umg}$ protein $\left.^{-1}\right)$ (A) and catalase activity ( $\mu \mathrm{mol} \mathrm{min} \mathrm{mg}^{-1}$ protein) (B) in muscle tissues of sea trout (S. trutta) at different developmental stages. 


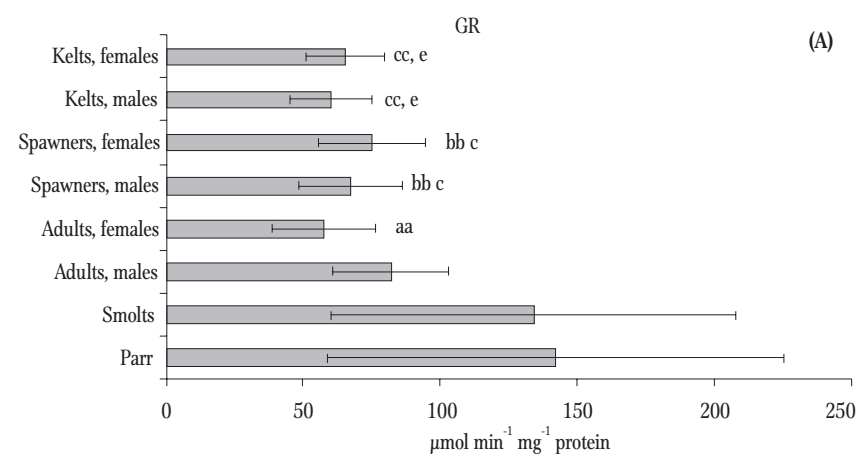

GPx

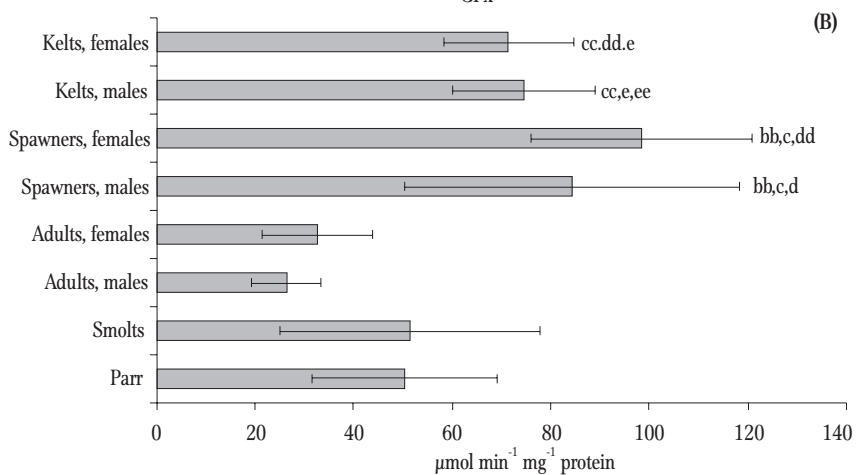

The developmental-induced changes in the activities of transaminases in muscle tissues were found to be highly specific. Our results revealed that alanine aminotransferase activity (AlAT, $\mathrm{F}_{7.364}$ $=22.56, \mathrm{P}=0.000$ ) changed statistically significantly at developmental stages, and there were significant decreases in smolts and spawners (both males and females). The activity of aspartate aminotransferase $\left(\mathrm{F}_{7.364}=44.79, \mathrm{P}=0.000\right)$ was observed to be lower in spawners (both males and females) and kelts (both males and females). These results are presented in Fig. 5.

The biochemical biomarkers of oxygen-dependent and oxygen-independent pathways of metabolism such as pyruvate $\left(\mathrm{F}_{7.364}=12.99, \mathrm{P}=\right.$ $0.000)$ and lactate $\left(\mathrm{F}_{7.364}=26.54, \mathrm{P}=0.000\right)$ are shown in Fig. 6. Our results revealed that developmental stages had a significant effect on the decrease of pyruvate levels only in the muscle of

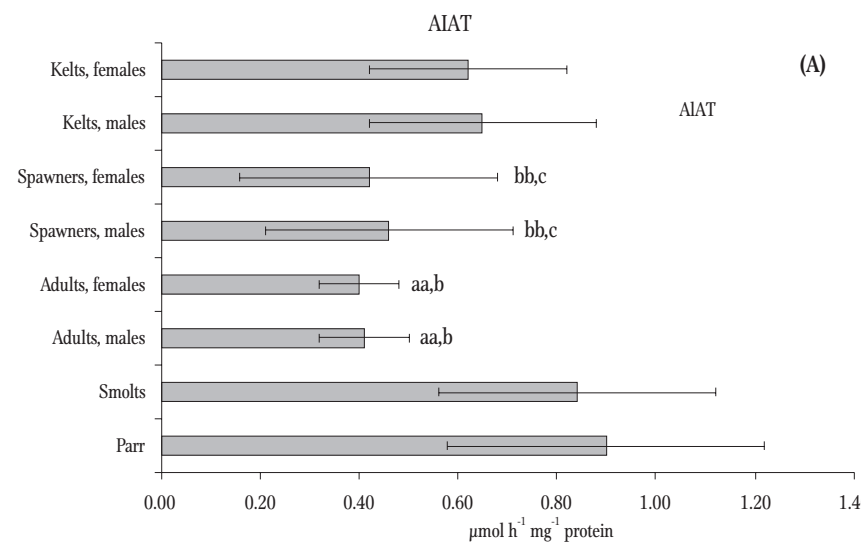
$\mathrm{min}^{-1} \mathrm{mg}^{-1}$ protein) (A) and glutathione peroxidase activity

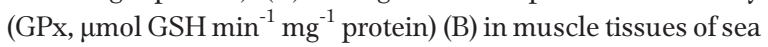
trout ((S. trutta) at different developmental stages.

The four different MANOVA tests presented in Table 1 confirmed the influence of the main factors, sex and developmental stage, and the combination of these factors on the formation of the antioxidant defense in sea trout muscle tissues. The SS test allowed us to draw the following conclusions on the role of each parameter analyzed as an integral model (Table 2). These dependencies are as follows: TBARS $>\mathrm{GPx}>\mathrm{SOD}>\mathrm{CAT}>\mathrm{GR}$, and they designated GPx, SOD, and TBARS as effective biomarkers of oxidative stress.

The dynamics of enzyme activity and the metabolites involved in metabolic changes revealed the use of the main energy substrates in different stages of trout development. Therefore, the next goal of the current study was to determine the activities of alanine and aspartate transaminases, lactate dehydrogenase, and succinate dehydrogenase and the level of energy metabolites (lactate and pyruvate) in sea trout muscle tissues.

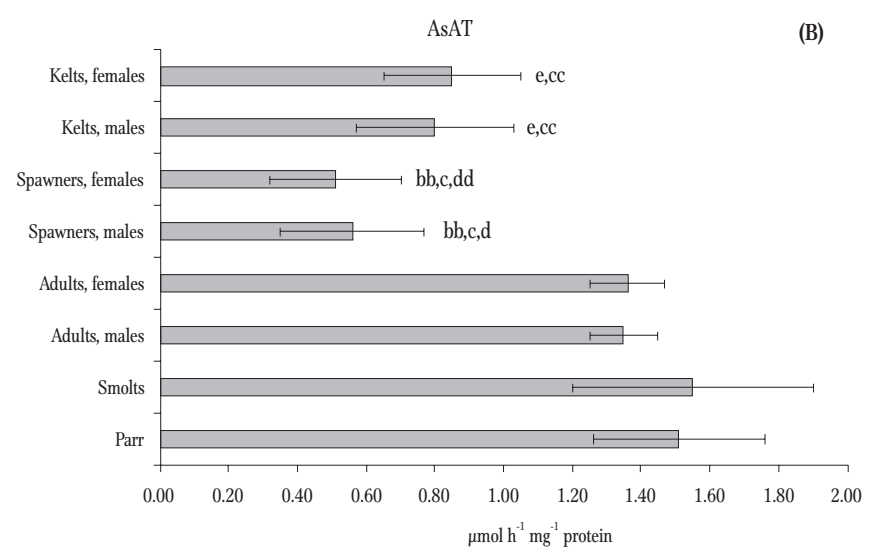

Figure 5. Alanine aminotransferase activity (AlAT, $\mu \mathrm{mol} \mathrm{h}^{-1} \mathrm{mg}^{-1}$ protein) (A) and aspartate aminotransferase activity (AsAT, $\mu \mathrm{mol} \mathrm{h}^{-1} \mathrm{mg}^{-1}$ protein) (B) in muscle tissues of sea trout (S. trutta) at different developmental stages. 
Table 1

Multivariate significance tests and effective hypothesis decomposition of antioxidant biomarkers in the muscle tissues of three sea trout (S. trutta) stages (adults, spawners, and kelts)

\begin{tabular}{lllll}
\hline \hline Effects & Tests & Test value & F & P \\
\hline \hline Sex & Wilks & 0.9104 & 2.498 & 0.034 \\
& Pillai & 0.0896 & 2.498 & 0.034 \\
& Hotelling & 0.0984 & 2.498 & 0.034 \\
& Roy & 0.0984 & 2.498 & 0.034 \\
Development stages & Wilks & 0.0842 & 62.140 & 0.000 \\
& Pillai & 1.1490 & 34.565 & 0.000 \\
& Hotelling & 8.1082 & 102.164 & 0.000 \\
Sex and Development stages & Roy & 7.7509 & 198.422 & 0.000 \\
& Wilks & 0.7605 & 3.726 & 0.000 \\
& Pillai & 0.2422 & 3.924 & 0.000 \\
& Hotelling & 0.3114 & 3.924 & 0.000 \\
& Roy & 0.2996 & 7.671 & 0.000 \\
\hline \hline
\end{tabular}

Table 2

SS test for a complete model of the formation of the antioxidant profile in sea trout ( $S$. trutta) muscle tissues at three developmental stages (adults, spawners, and kelts)

\begin{tabular}{llllll}
\hline \hline Parameters & Multiple $\mathrm{R}$ & Multiple $\mathrm{R}^{2}$ & Multiple adjusted $\mathrm{R}^{2}$ & $\mathrm{~F}$ & $\mathrm{P}$ \\
\hline \hline TBARS & 0.931 & 0.867 & 0.862 & 171.43 & 0.000 \\
SOD & 0.712 & 0.506 & 0.487 & 26.85 & 0.000 \\
CAT & 0.653 & 0.426 & 0.404 & 26.85 & 0.000 \\
GR & 0.384 & 0.147 & 0.115 & 4.52 & 0.001 \\
GPx & 0.755 & 0.569 & 0.554 & 34.72 & 0.000 \\
\hline \hline
\end{tabular}

Table 3

Multivariate significance tests and effective hypothesis decomposition of metabolic biomarkers in the muscle tissues of three sea trout (S. trutta) stages (adults, spawners, and kelts)

\begin{tabular}{lllll}
\hline \hline Effects & Tests & Test value & F & P \\
\hline \hline Sex & Wilks & 0.992 & 0.194 & 0.964 \\
& Pillai & 0.008 & 0.194 & 0.964 \\
& Hotelling & 0.008 & 0.194 & 0.964 \\
Development stages & Roy & 0.008 & 0.194 & 0.964 \\
& Wilks & 0.212 & 29.406 & 0.000 \\
& Pillai & 0.881 & 20.152 & 0.000 \\
\multirow{5}{*}{ Sex and Development stages } & Hotelling & 3.211 & 40.448 & 0.000 \\
& Roy & 3.065 & 78.459 & 0.000 \\
& Wilks & 0.912 & 1.192 & 0.296 \\
& Pillai & 0.089 & 1.189 & 0.298 \\
& Hotelling & 0.095 & 1.195 & 0.294 \\
\hline \hline
\end{tabular}



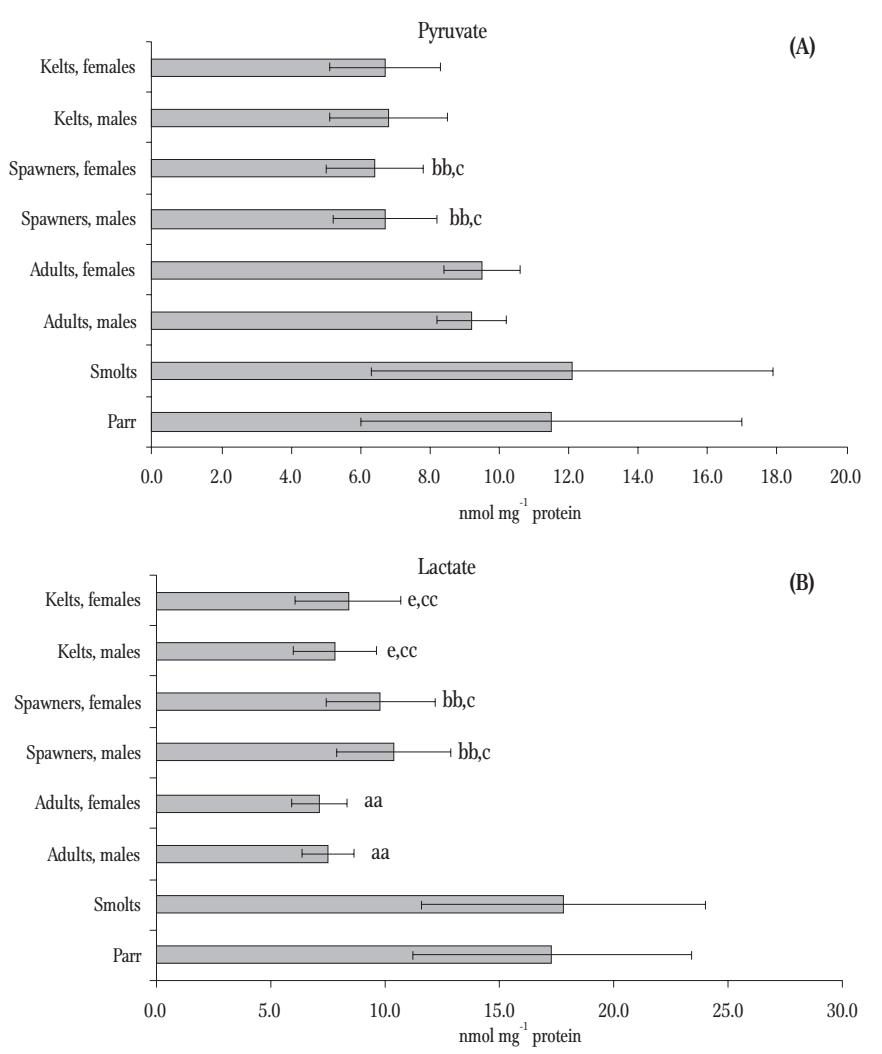

Figure 6. Pyruvate (nmol $\mathrm{mg}^{-1}$ protein) (A) and lactate (nmol mg ${ }^{-1}$ protein) level (B) in muscle tissues of sea trout (S. trutta) at different developmental stages.

spawners (both males and females). Statistically significant changes were noted in adult individuals (both males and females) compared with parr, and similar decreasing tendencies in lactate levels were also observed in spawners and kelts (both males and females).

The activity of enzymes involved in metabolic oxygen-dependent processes such as lactate dehydrogenase (LDH) and succinate dehydrogenase $(\mathrm{SDH})$ is presented in Fig. 7. The results demonstrated the wave-like dependence of LDH activity $\left(\mathrm{F}_{7.364}=6.07, \mathrm{P}=\right.$ 0.000 ) in each developmental stage. Our results indicated significant dependencies in the activities of $\mathrm{LDH}$ and SDH in muscle tissues only in smolts, male spawners, and female kelts. Similar developmental-related wave-like dependencies were shown in SDH activity $\left(\mathrm{F}_{7.364}=27.01, \mathrm{P}=0.000\right)$. It should be noted that the highest value of $\mathrm{SDH}$ activity was observed in male and female spawners; the reverse effect, namely the lowest value, was found for $\mathrm{LDH}$ activity in these groups.

The MANOVA test only revealed statistically significant relationships in some developmental stages. The data are presented in Table 3. Our results revealed that the biochemical markers of the oxygen-dependent pathways in muscle tissues were not influenced by sex. The SS test used to reveal the profile of biomarkers involved in metabolic changes of the main energy-related substrates demonstrated the role of each of these parameters in the formation of the complete model (Table 4). These dependencies are as follows: AsAT $>$ LDH $>$ Pyruvate $>$ SDH $>$ AlAT .
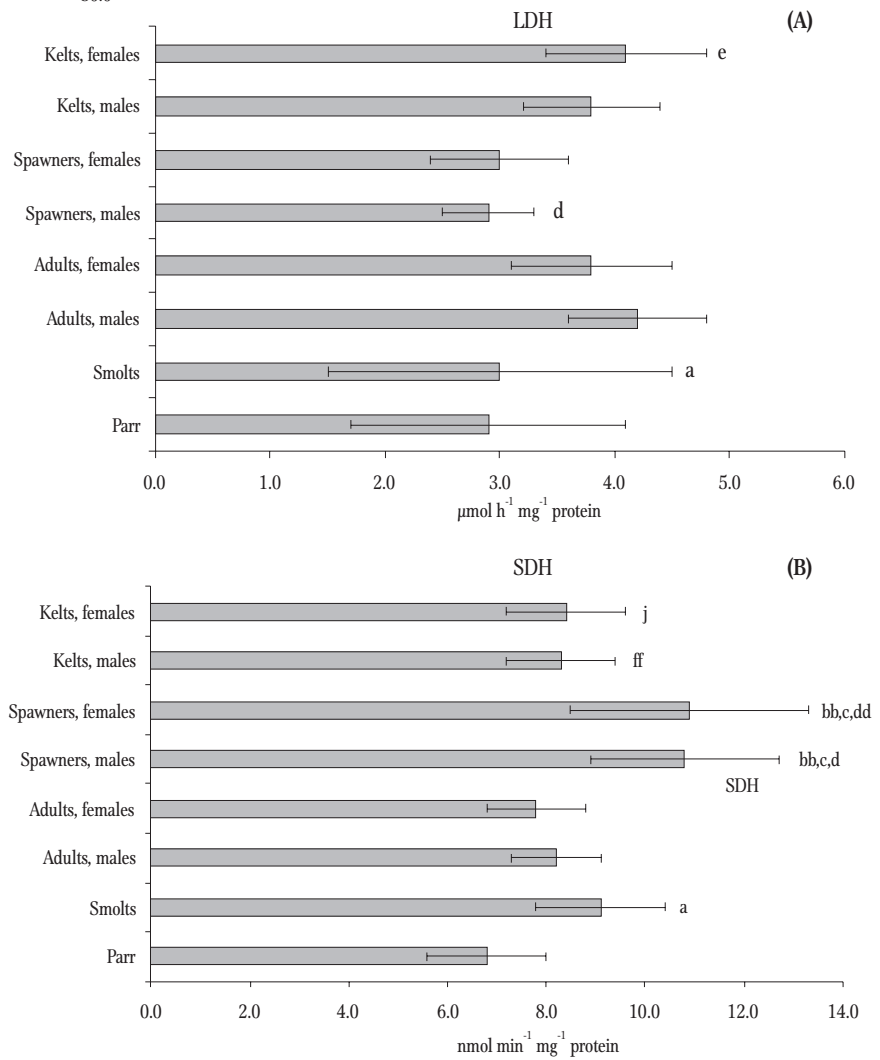

Figure 7. Lactate dehydrogenase activity (LDH, $\mu \mathrm{mol}$ pyruvate $\mathrm{h}^{-1} \mathrm{mg}^{-1}$ protein) (A) and succinate dehydrogenase activity ( $\mathrm{SDH}, \mathrm{nmol}$ succinate $\mathrm{min}^{-1}$ $\mathrm{mg}^{-1}$ protein) (B) in muscle tissues of sea trout (S. trutta) at different developmental stages. 
Table 4

SS test for the complete model of the metabolic profile in sea trout ( $S$. trutta) muscle tissues at three developmental stages of (adults, spawners, and kelts)

\begin{tabular}{llllll}
\hline \hline Parameters & Multiple R & Multiple $\mathrm{R}^{2}$ & Multiple adjusted $\mathrm{R}^{2}$ & $\mathrm{~F}$ & $\mathrm{P}$ \\
\hline \hline AsAT & 0.772 & 0.596 & 0.580 & 38.60 & 0.000 \\
Pyruvate & 0.532 & 0.283 & 0.256 & 10.32 & 0.000 \\
Lactate & 0.370 & 0.137 & 0.104 & 4.15 & 0.002 \\
LDH & 0.583 & 0.340 & 0.315 & 13.49 & 0.000 \\
SDH & 0.496 & 0.246 & 0.217 & 8.53 & 0.000 \\
AlAT & 0.343 & 0.117 & 0.083 & 3.48 & 0.006 \\
\hline \hline
\end{tabular}

\section{Discussion}

The objective of the current study was to determine the relationships between some enzymes and substrates involved in oxygen-dependent reactions in sea trout muscle tissues. The current study revealed the impact of sea trout sex and developmental stage (parr, smolts, spawners, adults, and kelts) on the effective formation of adaptive oxygen-dependent mechanisms. Changes in the activity of metabolic enzymes are caused by the modification of energy metabolism pathways, especially at spawning since reproduction is an energy-intensive process that requires the fish use significant internal reserves (Laiz-Carrion et al. 2002, Bartelme 2006). Thus, the redistribution of energy and plastic materials occurred as was evidenced by changes in the levels of substrates for aerobic and anaerobic-related metabolic pathways, and, accordingly, the intensification of lipid peroxidation.

There are several novel findings in our study. First, our results revealed a two-fold higher TBARS level in muscle tissues of spawners and kelts compared with the first three stages of trout development (parr, smolts, and adults). A stable, developmental-related tendency toward increased lipid peroxidation in muscle tissues was observed. These changes were substantial for the spawners and kelts and differed between the sexes. Products of lipid peroxidation are cytotoxic, mutagenic, and carcinogenic (Hensley et al. 2000). The gametogenesis processes and increased muscle activity with simultaneous fish starvation during spawning suggested uncontrolled oxidative reactions affecting their physiological states that led to exhaustion. The immune system of fish during this critical period of their life is vulnerable to infections caused by pathogens (Kurhalyuk et al. 2011a, 2011b, Tkachenko et al. 2014).

Second, glutathione peroxidase plays the leading role among the four antioxidant enzymes (SOD, CAT, GR, and GPx) in muscle tissues in different stages of trout development. Oxidative stress induces transformations in the functioning of the cellular energy system that are generally characterized by decreased succinic dehydrogenase activity and increased lactate dehydrogenase activity, i.e., the key enzymes of aerobic- and anaerobic-related metabolism in the liver and muscles. Similar metabolic alterations in these organs (muscles, liver) often proceed via reversible processes of energy metabolism, because energy is usually acquired in aerobic pathways from the liver and in anaerobic pathways from the muscles (Hochachka and Somero 2002).

Third, our data on the antioxidant defenses in the muscle tissues of sea trout analyzed with MANOVA tests confirmed the influence of sex and developmental stage and these two factors combined. Nevertheless, no such dependencies were observed regarding the activity of enzymes such as alanine and aspartate transaminases, lactate dehydrogenase, succinate dehydrogenase, or the metabolites involved in energy-related cellular metabolic changes (i.e., lactate and pyruvate). The results of multiple correlation analyses revealed that the biochemical markers of 
oxygen-dependent pathways in muscle tissues were not dependent on fish sex.

Lactate as a marker of anaerobic metabolism accumulates as the end product of glycolysis when oxidative phosphorylation and the Krebs cycle are inhibited. Since pyruvate is reduced to lactate by lactate dehydrogenase in anaerobic conditions, the simultaneous determination of pyruvate and lactate levels is valuable for assessing the predominance of aerobic or anaerobic metabolic pathways. The assessment of the lactate and pyruvate ratio ( $\mathrm{L} / \mathrm{P}$ ratio) revealed the prevalence of aerobic/anaerobic metabolism reflecting a cytosolic ratio of reduced and oxidized NAD $\left(\mathrm{NAD}^{+}\right.$and $\left.\mathrm{NADH}^{+}\right)$. Therefore, the $\mathrm{L} / \mathrm{P}$ ratio was a more reliable parameter for estimating the cellular energy state, referred to as the adenylate energy charge, concerning ATP, ADP, and AMP concentrations (Zoremba et al. 2014).

In our study, we noted increased lactate levels and higher $\mathrm{L} / \mathrm{P}$ ratios in the muscle tissues of parr and smolts compared to those in other developmental stages. This increase in lactate levels and the $\mathrm{L} / \mathrm{P}$ ratio was similar to that in the production of lactic acid via aerobic to anaerobic metabolic pathways. These changes could be related to the almost complete dissociation of lactic acid in aqueous solutions to lactate and protons accompanied by severe acidosis. The increasing stress-induced hypoxia caused by the fish moving from fresh water to saltwater during the parr and smolt stages can decrease ATP production and stimulate glycolysis. These mechanisms triggered by phosphofructokinase mechanisms and NAD initiated the conversion of pyruvate to lactate. In our study, the lowest $\mathrm{L} / \mathrm{P}$ ratio in muscle tissues was observed in adults (both males and females). This stage was characterized by enhancing the adaptive mechanisms of the oxygen-redistribution process in the sea habitat. In our study, an increase in the $\mathrm{L} / \mathrm{P}$ ratio was observed in spawners. This increase reflected the switch of the muscle cytosolic redox potential from the aerobic pathway to anaerobic glycolysis. These results indicated that energy-related cellular components and metabolic enzymes (e.g., succinic dehydrogenase) could compensate for adaptive mechanisms without any serious damage to muscle tissues (Phypes and Pierce 2006).

Potentially, the differences in enzyme activities are associated with the reorganization of the energy-related metabolic pathways (anaerobic and aerobic) during spawning. This process is one of the ways that fish adapt to effectively use potential benefits associated with, for example, changes in the temperature conditions of the environments (Hochachka and Somero 2002). The main physiological changes in the fish developmental stages (spawning, growth, accumulation of energy reserves) are confined to the most favorable seasons of the year (Shulman and Love 1999).

Succinate dehydrogenase (SDH) catalyzes the reactions of $\mathrm{NADH}_{2}$ and $\mathrm{FADH}_{2}$ and the conversion of succinate to fumarate. Changes in SDH activity (sensitivity) in response to environmental factors in wild fish in aquatic ecosystems have not been fully elucidated in the literature (Kurhaluk 2019). Several researchers report the influences of neurohormonal, morphological, and biochemical changes caused by fish developmental stages, migration from one habitat to another (freshwater and seawater), hormonal differences between the sexes, migration-induced stress reactions, starvation during spawning, and the spawning process itself (Solan and Whiteley 2016, Kurhaluk 2019).

Fourth, the role of AsAT was crucial in the formation of the complete statistical model of the profile of selected biomarkers involved in metabolic changes in sea trout muscle tissues. Not only were the dynamics of aminotransferases activity essential, but primarily the AsAT/AlAT ratio (De Ritis ratio) was significant, and our results confirmed this (Botros and Sikaris 2013). Blood AlAT and AsAT activities are commonly requested panel tests for the diagnosis of liver and heart diseases. The release of AlAT and AsAT from liver cells to the bloodstream represents hepatocellular damage caused by the intensity of metabolic processes or pathological disorders. These enzymes represent the equilibrium between the normal turnover of hepatocytes and the clearance of enzymes from plasma (Botros and Sikaris 2013). Our study confirmed the increase of the De Ritis ratio in 
sea trout muscle tissues through the developmental stages from parr to adult (males and females). The highest value of the De Ritis ratio was observed in the adult stage (females), while the lowest value was noted in spawners (females). A decrease in the De Ritis ratio was observed in muscle tissues of sea trout in the spawning period and in kelts when compared with parr, smolts, and spawners (male and female).

Other dependencies of these enzymes on sex were studied by Lun et al. (2006), who demonstrated the role of aminotransferases in the development of fish gonads. The relationship between hepatic aminotransferases and gonads is well known. In the ancestor of all chordates, the lancelet, AlAT is present only in the liver diverticulum and gonads and is absent in muscles and other tissues, unlike in other chordates, including fish. AlAT, like vitellogenin, is synthesized in the liver and then transported to the gonads, where it participates in their maturation (Lun et al. 2006). Enzyme activity is higher in salmon testes than in ovaries, and the development of ovaries during the feeding season of this species is close to the completion of vitellogenesis, while the testes are characterized by the beginning of active spermatogenesis, in which intense transamination processes are observed (Dorohova 2013).

\section{Conclusions}

The current study revealed the impact of the sex and different developmental stages of sea trout (parr, smolts, spawners, adults, and kelts) on the effective formation of adaptive oxygen-dependent mechanisms. The results of our study revealed a two-fold higher TBARS level (a lipid peroxidation level) in muscle tissues of spawners and kelts compared to the first three stages of trout development (parr, smolts, and adults). A stable, developmental-related tendency toward an increase in the lipid peroxidation in muscle tissues was observed. Glutathione peroxidase in muscle tissues played a leading role in the different trout development stages. Increased lactate levels and higher $\mathrm{L} / \mathrm{P}$ ratios in the muscle tissues of parr and smolts compared to those of the other developmental stages were observed. This increase reflected the muscle cytosolic redox potential switching from the aerobic pathway to anaerobic glycolysis. These results indicated that energy-related cellular components and metabolic enzymes (e.g., succinic dehydrogenase) could compensate for adaptive mechanisms without any serious damage to muscle tissues. Our study confirmed increased De Ritis ratios in sea trout muscle tissues through the developmental stages from parr to adults (males and females). The differences in the enzyme activities were associated with the reorganization of energy-related metabolic pathways (anaerobic and aerobic) during spawning. This process was one of the ways fish adapted to changing habitats as they migrated between fresh water and seawater.

Acknowledgments. The authors would like to thank Katarzyna Pałczyńska-Guguła for technical assistance in analyzing of the samples. The authors are grateful to the authorities of the Dolina Słupia Landscape Park and the District Board of the Polish Angling Association in Słupsk for providing logistics support during sample collection.

Author contributions. N.K., H.T. conceived of and designed the study, revised it critically, performed analyses, interpreted data, and drafted the paper. All of the authors approved the final version of the manuscript and agreed to be accountable for all aspects of the work in ensuring that questions related to the accuracy or integrity of any part of it are appropriately investigated and resolved. All persons designated as authors quality for authorship and all those who qualify for authorship are listed.

ORCID ID

Natalia Kurhaluk: (iD https://orcid.org/0000-0002-4669-1092

\section{References}

Amundsen P.-A., Gabler H.-M., Riise L.S. 2001 - Intraspecific food resource partitioning in Atlantic salmon (Salmo salar) parr in a subarctic river - Aquat. Living Resour. 14: 257-265. 
Bartelme D. 2006 - Metabolism, energy use and feeding behaviors in fish diseases - Advanced Aquarists 1: 3-26.

Birt T.P., Green J.M. 1986 - Parr-smolt transformation in female and sexually mature male anadromous Atlantic salmon Salmo salar - Can. J. Fish. Aquat. Sci. 43: 680-686.

Botros M., Sikaris K.A. 2013 -The De Ritis Ratio: The Test of Time. - The Clinical Biochemist Reviews 34: 117-130.

Bradford M.M. 1976 - A rapid and sensitive method for the quantitation of microgram quantities of protein utilizing the principle of protein-dye binding - Anaytical Biochemistry 72 : $248-254$.

Costantini D. 2018 - Meta-analysis reveals that reproductive strategies are associated with sexual differences in oxidative balance across vertebrates - Curr. Zool. 64: 1-11.

Dal Bosco A., Mugnai C., Roscini V., Castellini C. 2013 - Fillet fatty acid composition, estimated indexes of lipid metabolism and oxidative status of wild and farmed Brown Trout (Salmo trutta L.) - Ital. J. Food Sci. 25: 83-89.

Debowski P., Glogowski J., Dobosz S., Robak S. 1999 - Gill $\mathrm{Na}^{+}, \mathrm{K}^{+}$-ATPase activity and body silvering as indices of smoltification of hatchery-reared sea trout - Arch. Pol. Fish. 7: 245-256.

Dorohova I.I. 2013 - Sexual features of the activity of aminotransferases in the liver of Black Sea fishes. - In: Biodiversity and the role of animals in ecosystems, Adverta, Dnipropetrovsk: 90-91.

Dziewulska K., Krzemieniecki A., Domagała J. 2008 - Basic physico-chemical parameters of milt from sea trout (Salmo trutta m. trutta), brook trout (Salvelinus fontinalis) and rainbow trout (Oncorhynchus mykiss) - J. Appl. Ichthyol. 24: 497-502.

Eschenko N.D., Volski G.G. 1982 - Determination of succinic acid level and succinate dehydrogenase activity - In: Methods of biochemical study. Sankt-Petersburg National University, Leningrad (in Russian).

Ferguson A, Reed TE, Cross TF, McGinnity P, Prodöhl PA. 2019 - Anadromy, potamodromy and residency in brown trout Salmo trutta: the role of genes and the environment - J. Fish Biol. 95: 692-718.

Gabriel U.U., Akinrotimi O.A., Ariweriokuma V.S. 2012 Changes in metabolic enzymes activities in selected organs and tissue of Clarias gariepinus exposed to cypermethrin - J. Environ. Eng. Tech. 1: 13-19.

Glatzle D., Vuilleumier J.P., Weber F., Decker, K. 1974 Glutathione reductase test with whole blood, a convenient procedure for the assessment of the riboflavin status in human - Experientia 30: 665-666.

Guéraud F., Atalay M., Bresgen N., Cipak A., Eckl P.M., Huc L., Jouanin I., Siems W., Uchida K. 2010 - Chemistry and biochemistry of lipid peroxidation products - Free Radic. Res. 44: 1098-1124.
Halliwell B., Gutteridge J. 2007 - Free Radicals in Biology and Medicine. Fourth ed. - Oxford University Press, New York.

Hensley K., Robinson K.A., Gabbita S., Salsman S., Floyd R.A., 2000 - Reactive oxygen species, cell signaling, and cell injury - Free Radical Biol. Med. 28: 1456-1462.

Herasimov I., Plaksina O. 2000 - Non enzymatic determination of lactate and pyruvate concentrations in blood sample - Laboratorna Diagnostyka 2: 46-48 (in Ukrainian).

Hochachka P.W., Somero G.N. 2002 - Biochemical adaptation: mechanism and process in physiological evolution. New York: Oxford University Press, 480 p.

Jensen A.J., Johnson B.O. 1982 - Difficulties in aging Atlantic salmon (Salmo salar) and brown trout (Salmo trutta) from cold rivers due to lack of scales as yearlings - Can. J. Fish. Aquat. Sci. 39: 321-325.

Kamyshnikov V.S. 2004 - Reference book on clinic and biochemical researches and laboratory diagnostics. MEDpress-inform, Moscow (in Russian).

Koroliuk M.A., Ivanova L.I., Majorova I.G., Tokarev V.E. 1988 - A method of determining catalase activity Laboratornoe Delo 1: 16-19 (in Russian).

Kostiuk V.A., Potapovich A.I., Kovaleva Zh.V. 1990 - A simple and sensitive method of determination of superoxide dismutase activity based on the reaction of quercetin oxidation. - Biomeditsinskaya Khimiya 36: 88-91 (in Russian).

Kurhaluk N. 2019 - Formation of an antioxidant profile in the sea trout (Salmo trutta m. trutta L) from the Slupia River - Zoology 133: 54-65.

Kurhalyuk N., Tkachenko H., Palczynska, K. 2011a - Resistance of erythrocytes from brown trout (Salmo trutta m. trutta L.) affected by ulcerative dermal necrosis syndrome - Pol. J. Vet. Sci. 14: 443-448.

Kurhalyuk N., Tkachenko H., Palczynska K., Wysocka-Lipinska N. 2011b - The influence of ulcerative dermal necrosis on antioxidant defence system of spawn and milt of sea trout (Salmo trutta m. trutta L.) from basin of river Slupia during spawning - Słupskie Prace Biol. 8: 73-88.

Laiz-Carrion R., Sangiao Alvarellos S., Guzman J., Martin M., Miguez J., Soengas J., Mancera J. 2002 - Energy metabolism in fish tissues related to osmoregulation and cortisol action: Fish growth and metabolism. Environmental, nutritional and hormonal regulation - Fish Physiol. Biochem. 27: 179-188.

Lun L.M., Zhang S.C., Liang Y.J. 2006 - Alanine aminotransferase in amphioxus: Presence, localization and up-regulation after acute lipopolysaccharide exposure - J. Biochem. Mol. Biol. 39: 511-515.

Maitre D., Selmoni O.M., Uppal M, Cunha L.M., Wilkins L.G. E., Roux J., Kenyon B. Mobley K.B., Castro I., Knörr S., Robinson-Rechavi M., Wedekind C. 2017 - Sex differentiation in grayling (Salmonidae) goes through an all-male 
stage and is delayed in genetic males who instead grow faster - Sci. Rep. 7: 15024 .

Martines-Alvares R.M., Morales A.E, Sanz A. 2005 - Antioxidant defenses in fish: Biotic and abiotic factors - Rev. Fish Biol. Fish. 15: 75-88.

Martínez P., Vińas A.M., Sánchez L., Díaz N., Ribas L. Piferrer F. 2014 - Genetic architecture of sex determination in fish: applications to sex ratio control in aquaculture Front. Genet. 5: 340.

Moin V.M. 1986 - A simple and specific method for determining glutathione peroxidase activity in erythrocytes Laboratornoe Delo 12: 724-727 (in Russian).

Obolewski K. 2010 - Use of Macroinvertebrates as Bioindicators for the Assessment of Surface Water Quality in Urban Areas: A Case Study. - Ochr. Sr. 32: 35-42.

Pedersen S., Christiansen R., Glusing H. 2006 - Comparison of survival, migration and growth in wild, offspring from wild (F1) and domesticated sea-run trout (Salmo trutta L.) - In: Sea Trout: Biology, Conservation and Management (Eds) G. Harris, N. Milner, Blackwell Publishing Ltd, Oxford.

Pemberton R.G. 1976 - Sea trout in the North Argyll sea lochs; 1: Population, distribution and movements - J. Fish Biol. 9: 157-179.

Phypers B., Pierce T. 2006 - Lactate physiology in health and disease - Contin. Educ. Anaesth. Crit. Care Pain 6: 128-132.
Pratten D.J., Shearer W.M. 1983 - Sea trout of the North Esc. - Fish Management 14: 49-65.

Reitman S., Frankel S. 1957 - A colorimetric method for determination of serum oxaloacetic and glutamic pyruvic transaminases - Am. J. Clin. Pathol. 28: 56-63.

Sevela M., Tovarek J. 1959 - A method for the estimation of lactic dehydrogenase - J. Czech Physiol. 98: 844-848.

Shulman G.E., Love R.M. 1999 - The Biochemical Ecology of Marine Fishes - Advances in Marine Biology, Acad. Press, San Diego.

Solan M., Whiteley N 2016 - Stressors in the Marine Environment: Physiological and ecological responses; societal implications - Oxford University Press, Oxford.

Tkachenko H., Kurhaluk N., Andriichuk A., Gasiuk E., Beschasniu, S. 2014 - Oxidative Stress Biomarkers in Liver of Sea Trout (Salmo trutta m. trutta L.) affected by Ulcerative Dermal Necrosis Syndrome. - Turk. J. Fish. Aquat. Sci. 14: 391-402.

Zar J.H. 1999 - Biostatistical Analysis $-4^{\text {th }}$ ed., Prentice Hall Inc., New Jersey.

Zoremba N., Homola A., Rossaint R., Syková E. 2014 - Interstitial lactate, lactate/pyruvate and glucose in rat muscle before, during and in the recovery from global hypoxia Acta Vet. Scand. 56: 72. 